\title{
Negative results for anti-Leptospira sp. agglutinins in free-living Iguanas (Iguana iguana) from the Amazon region of Brazil
}

\section{Thamillys Rayssa Marques Monteiro ${ }^{1}$ Katarine de Souza Rocha ${ }^{1}$ Gleiciane Schupp de Sena Mesquita ${ }^{1}$ Danniel Carvalho de Castro ${ }^{2}$ Stefânia Araújo Miranda ${ }^{3}$ Giselle Souza da Paz $^{4}$ (-) Hélio Langoni ${ }^{5}$ Carla Cristina Guimarães de Moraes $^{{ }^{*}}$ C}

\author{
${ }^{1}$ Laboratório de Zoonoses e Saúde Pública, Universidade Federal do Pará (UFPA), 68746-360, Castanhal, PA, Brasil. E-mail: ccmoraes@ufpa.br. \\ ${ }^{*}$ Corresponding author. \\ ${ }^{2}$ Universidade Rural da Amazônia (UFRA), Belém, PA, Brasil. \\ ${ }^{3}$ Parque Mangal das Garças, Belém, PA, Brasil. \\ ${ }^{4}$ Laboratório de Micologia Médica, Departamento de Microbiologia e Imunologia, Instituto de Biociências, Universidade Estadual Paulista \\ "Júlio de Mesquita Filho" (UNESP), Botucatu, SP, Brasil. \\ ${ }_{5}^{5}$ Departamento de Higiene Veterinária e Saúde Pública, Faculdade de Medicina Veterinária e Zootecnia, Universidade Estadual Paulista "Júlio \\ de Mesquita Filho" (UNESP), Distrito de Rubião Junior, Botucatu, SP, Brasil.
}

ABSTRACT: Although, serological studies for leptospirosis in iguanas have already been performed, there is no report in the Amazon region. Therefore, the present study aimed to investigate the presence of anti-Leptospira sp. in free living Iguanas-verdes (Iguana iguana) of Mangal das Garças Park, metropolitan region of Belém, Pará, Northern region of Brazil. Twenty-nine blood samples of Iguana-verde (I. iguana) were collected from Mangal das Garças Park. For the serological diagnosis of Leptospira sp. it was employed microscopic agglutination test (MAT) with 25 live antigens of Leptospira sp. as antigens. It was observed that all samples were non-reactive, suggesting no exposure to the agent. Key words: reptiles, leptospirosis, wild animals, Amazon.

Resultados negativos para aglutininas anti-Leptospira sp. em iguanas de vida livre (Iguana iguana) da região amazônica do Brasil

RESUMO: Embora estudos sorológicos para leptospirose em iguanas já tenham sido realizados, não a relatos na região amazônica. Portanto, o presente trabalho teve como objetivo pesquisar a presença de anticorpos anti-Leptospira sp. em Iguanas-verdes (Iguana iguana) de vida livre do Parque Mangal das Garças, região metropolitana de Belém, PA, e Norte do Brasil. Foram coletadas 29 amostras de sangue de Iguanaverde (I. iguana) que frequentaram o Parque Mangal das Garças. Para o diagnóstico sorológico da infecção por Leptospira sp. foi empregado o teste de aglutinação microscópica (MAT) com 25 antígenos vivos de Leptospira sp. como antígenos. Observou-se que todas as amostras foram não reagentes, o que sugere não exposição ao agente.

Palavra-chave: répteis, leptospirose, animais silvestres, Amazônia.

The iguana is a reptile of the family Iguanidae. Of more than 35 species of iguana, only one type, Iguana iguana, popularly known as the green iguana, sinimbu, or chameleon, is indigenous to Brazil. These animals are found in the Amazon, Cerrado, Pantanal, Caatinga, and the Atlantic Forest (ANDRADE, 2009). The search for food, shelter, and places to sunbathe and mate, as well as enclosures for the construction of nests, has led to the presence of iguanas in different environments (BAYER CORPORATION, 2002). Thus, these reptiles may play an important role in the epidemiology of zoonotic diseases due to the maintenance of infectious agents, such as Leptospira sp., in the environment and their spread to other animals (LINDTNER-KNIFIC et al., 2013).

Leptospirosis is a global anthropozoonosis that affects humans and domestic and wild animals
(MCBRIDE et al., 2005). Domestic and wild mammals may be natural reservoirs or accidental hosts of several serotypes. Although, studies reporting the exposure of free-living reptiles to infectious pathogens are limited, knowledge concerning this population is important, given the attempts to reintroduce or translocate reptiles (CALLE et al., 2001). ROSSETTI et al. (2003) identified 67 reactive crocodiles (22 free-living) in which the possible infectious path was the aquatic environment that they inhabited, demonstrating a means of Leptospira persistence.

Accordingly, in this study, we aimed to assess the presence of anti-Leptospira sp. antibodies in free-living green iguanas from the Mangal das Garças Park located in the urban center of the metropolitan region of Belém, Pará, Brazil. For 30 consecutive 
days, green iguanas were fed with various fruits, cabbage, and boiled eggs, always at the same time and place. Following this adaptation period, the animals were captured with dip nets during feeding and physically restrained at the base of the neck, pelvic limbs, and tail. Care was taken to avoid stress as much as possible. Following this procedure, the animals were placed in transport boxes and sent to the park clinic for blood sample collection. In accordance with the animals diurnal habits, blood collections were performed in the morning on a single day in three random locations in the park; 29 blood samples from young iguanas were collected by venipuncture of the jugular vein using disposable needles $(25 \times 0.7 \mathrm{~mm})$ and syringes $(3 \mathrm{~mL})$ and the blood was then transferred to anticoagulant-free blood collection tubes. Animals were immediately released after blood collection and none died.

Samples were taken to the Laboratory of Zoonosis and Public Health of the Federal University of Pará for centrifugation, serum collection, and storage at $-20^{\circ} \mathrm{C}$ until serological testing in the Zoonosis Diagnostic Service, Department of Veterinary Hygiene and Public Health, Faculty of Veterinary Medicine and Animal Husbandry FMVZ, Paulista State University "Júlio de Mesquita Filho" UNESP (Botucatu Campus). Anti-Leptospira sp. antibodies were detected using microscopic agglutination tests according to FAINE et al. (1999). Sera were diluted 1:50 and tested against 25 serotypes: Andamana, Australis, Autumnalis, Bataviae, Bratislava, Butembo, Canicola, Castellonis, Copenhageni, Cynopteri, Djasiman, Grippotyphosa, Hardjo, Hebdomadis, Icterohaemorrhagiae, Javanica, Panama, Patoc, Pomona, Pyrogenes, Sentot, Shermani, Tarassovi, Whitcombi, and Wolffi. Cells were maintained by weekly picking in EllinghausenMcCullough-Johnson-Harris (EMJH) liquid medium at $29^{\circ} \mathrm{C}$. Sera displaying $50 \%$ or greater agglutination compared with the control suspension were referred for determination of antibody titers.

All animals in this study had negative serology for detection of anti-Leptospira sp. antibodies. It should be noted that there are no studies on the health of green iguanas in the northern region of Brazil. The present study is the first report describing the serologic detection of Leptospira in free-living iguanas in the Amazon. However, the impact of this study was limited by the small number of animals examined. At the time of sample collection, the iguanas in this study may not have had sufficient levels of antibodies to be detected or may not have truly been exposed to the infectious agent.
According to MINETTE (1983), although the immune responses of iguanas have not been fully elucidated, they present undetectable antibody titers in serological tests, even when pathogenic Leptospira are present and active. Feeding, capturing, and handling animals in the wild present challenges for the study of these animals. In contrast, captive animals can be more easily studied (ULLMANN et al., 2012), and data concerning the transmission of Leptospira in lizards are more frequently reported in zoos and breeding grounds, where it was possible to verify circulation of the agent among cold-blooded animals, including I. iguana (SILVA et al., 2010), due to the greater proximity to different wild species and synanthropic animals, such as rodents, being the main reservoirs of the agent. LINDTNER-KNIFIC et al. (2013) identified two free-living iguanas with antibody titers of 1000 for the hardjo serotype, demonstrating that the animals had contact with the agent in their natural environment. In the present study the battery of live antigens used did not include any local isolate, which could possibly explain the negative results. In addition, the rodent control actions carried out at Mangal das Garças Park allow animals that circulate in the enclosure to not come into contact with the main reservoir of Leptospira. Thus, based on the results presented, the real role of these animals in the epidemiology of leptospirosis is unclear. Thus, the results obtained suggested that the Park's iguanas were not exposed to the agent.

\section{ACKNOWLEDGEMENTS}

We gratefully acknowledge the support of the National Council for Scientific and Technological Development $(\mathrm{CNPq})$ through a scientific initiation scholarship; the employees, interns, and technicians from the Mangal das Garças Environmental Park for their help and for allowing the collection of samples; and the Zoonosis Diagnostic Service (SDZ) of the Department of Veterinary Hygiene and Public Health, FMVZ, UNESP (Botucatu Campus) for the processing of samples.

\section{COMMITTEE OF ETHICS AND BIOSAFETY}

Authorization for the conduct of this study was obtained as follows: CEPAE-UFPA: no. 177-13 of the Animal Ethics Committee for the use of animals and the Biodiversity Information and Authorization System (SISBIO), issued on the basis of Normative Ruling no. 154/2007, by the authentication code: 59824466 , authorization for the collection of biological material.

\section{DECLARATION OF CONFLICTING OF INTERESTS}

The authors declare no conflict of interest. The founding sponsors had no role in the design of the study; in the 
collection, analyses, or interpretation of data; in the writing of the manuscript, and in the decision to publish the results.

\section{REFERENCES}

ANDRADE, C.A.F. 2009. Bicho da vez: Iguana-Verde (Iguana iguana) $\mathrm{n}^{\circ} 6$. Universidade Federal de Viçosa.

BAYER CORPORATION. 2002. Bayer Exotics Symposium: Selected papers on the green iguana and antimicrobials in exotic pets: presented at the North American Veterinary Conference. Veterinary Learning Systems, 44p.

CALLE, P.P et al. Infectious disease serologic survey in free-ranging venezuelan anacondas (Eunectes murinus). Journal of Zoo and Wildlife Medicine, v.32, n.3: p320-323. 2001. Available from: $<$ http:// www.bioone.org/doi/abs/10.1638/1042-7260(2001)032\%5B0320:I DSSIF\%5D2.0.CO;2>. Accessed: Jan. 01, 2017. doi:10.1638/10427260(2001)032[0320:IDSSIF]2.0.CO;2.

FAINE, S. et al. Leptospira and leptospirosis. Melbourne: Medisci, Australia, 1999. 272p.

LINDTNER-KNIFIC, R. et al. A prevalence of antibodies against Leptospira sp. In snakes, lizards and turtles in Slovenia. Acta Veterinaria Scandinavica, v. 55, n. 65, p.01-08. 2013. Available from: <https://doi.org/10.1186/1751-0147-55-65>. Accessed: Jul. 21, 2015. doi:10.1186/1751-0147-55-65.
MCBRIDE A.J. et al. 2005. A leptospirosis. Current opinion in infectious diseases v.18 n.5, p.376-386. Available from: <https:// www.arca.fiocruz.br/bitstream/icict/7554/1/McBride\%20AJA $\% 20$ Leptospirosis.pdf>. Accessed: Mar. 21, 2017. doi:10.1097/01. qco.0000178824.05715.2c.

MINETTE, H.P. Leptospirosis in poikilothermic vertebrates. A review. The international journal of zoonoses, v. 10 n.2, p.111121. 1983.

ROSSETTI, C.A. et al. Detection of leptospiral antibodies in caimans from the Argentinian Chaco. The Veterinary Record, v.153, n.20, p.632-633. 2003. Available from: <http:// dx.doi.org/10.1136/vr.153.20.632>. Accessed: Mar. 01, 2017. doi:10.1136/vr.153.20.632.

SILVA, C.S. et al. Anti-Leptospira spp. antibodies in wild animals from Ribeirão Preto city zoo in São Paulo State, Brazil. Brazilian Journal of Veterinary Research and Animal Science, v.47, n.3, p.237-242. 2010. Available from: <https://www.revistas.usp. br/bjvras/article/view/26862/28645>. Accessed: Jan. 11, 2016. doi:10.11606/issn.1678-4456.bjvras.2010.26862.

ULLMANN, L.S. et al. Epidemiology of leptospirosis at Sorocaba Zoo, São Paulo state, Southeastern Brazil. Brazilian Journal of Veterinary Research, v.32, n.11, p.1174-1178. 2012. Available from: $<$ http://www.scielo.br/scielo.php?script=sci_arttext\&pid=S0100736X2012001100017\&lng=en\&nrm=iso >. Accessed: Mar. 01, 2017. doi:10.1590/S0100-736X2012001100017. 